\title{
NATURAL HYBRIDIZATION BETWEEN TWO SPECIES OF GREEN ANOLES: MORPHOLOGICAL AND GENETIC EVIDENCE
}

\section{Hibridación natural entre dos especies de Anolis verdes: evidencia morfológica y genética}

\author{
Eveling Gabot-Rodríguez ${ }^{1 *}$, Sixto J. Incháustegui², Markus Pfenninger ${ }^{3 a}$, \\ Barbara Feldmeyer ${ }^{3 b}$, and Gunther Köhler ${ }^{4}$
}

\begin{abstract}
${ }^{1}$ Museo Nacional de Historia Natural "Prof. Eugenio de Jesús Marcano”. Calle César Nicolás Penson, Plaza de la Cultura Juan Pablo Duarte, Santo Domingo, República Dominicana. (Dorcid.org/0000-0003-4234-711X; *Correspondence: e.gabot@mnhn.gov.do. ${ }^{2}$ Grupo Jaragua, El Vergel \#33, El Vergel, Santo Domingo, República Dominicana. (D) orcid.org/0000-0002-7135-0871; ${ }^{3}$ Senckenberg Biodiversity and Climate Research Centre, Frankfurt am Main, Hessen, Germany; 3a (D) orcid.org/0000-0002-1547-7245; ${ }^{3 b}$ Dorcid.org/0000-0002-0413-7245; ${ }^{4}$ Senckenberg Forschungsinstitut und Naturmuseum, Senckenberganlage 25, 60325 Frankfurt am Main, Germany. (D) orcid.org/0000-0002-2563-5331.
\end{abstract}

\section{ABSTRACT}

Anoles are a group of lizards that offer a wide range of opportunities to study different biological topics. In this work, we examined some aspects of the morphology from 139 individuals of green anoles collected in urban parks of Santo Domingo and the Distrito Nacional. We investigated evidence of hybridization between the two Hispaniola endemic species Anolis chlorocyanus and $A$. cyanostictus and the introduced species $A$. porcatus. We categorized the individuals in pure species and intermediates based on their phenotype. Additionally, mitochondrial $16 \mathrm{~S}$ sequence data was generated from the collected specimens, to compare molecular and phenotypic species assignments. We consider the general congruence between both data sets in most but inconsistency in a few specimens as evidence for hybridization between the two endemic species. However, we did not find evidence of hybridization between any of these species and the introduced species $A$. porcatus. Nevertheless, the continuous expansion of the distribution of this invasive species possibly will have drastic negative consequences for the populations of the endemic species.

Keywords: Hispaniola, urban anoles, interspecific mating, intermediate morphology, gene introgression.

\section{RESUMEN}

Los Anolis son un grupo de lagartos que ofrecen una amplia gama de oportunidades para el estudio de diversos temas biológicos. En este trabajo, examinamos algunos aspectos de la morfología de 139 individuos de Anolis verdes presentes en parques urbanos de Santo Domingo y el Distrito Nacional. Nosotros investigamos evidencias morfológicas y genética de hibridación entre las dos especies endémicas de La Española, Anolis chlorocyanus y A. cyanostictus y la especie introducida A. porcatus. Basados en su fenotipo, clasificamos a los individuos en especies puras o intermedias. Además, se recopilaron datos mitocondriales $16 \mathrm{~S}$ para una comparación fenotípica y molecular. A partir de la asociación general entre los dos conjuntos de datos en la mayoría, pero la incongruencia en pocas muestras, concluimos sobre la presencia de hibridación entre las dos especies endémicas. Sin embargo, no se encontró evidencia de hibridación entre ninguna de estas especies y la especie introducida $A$. porcatus. A pesar de ello, la continua expansión de la distribución de esta especie invasora posiblemente tendrá consecuencias negativas drásticas para las poblaciones de las especies endémicas. 


\section{INTRODUCTION}

The Hispaniolan green anoles are a group of Anolis lizards characterized by having (among other morphological characteristics) brilliant-green body color in live, although capable of color changes to brown (Williams, 1965; Köhler \& Hedges, 2016). Like all members of this genus, they can be distinguished from other lizards by the combination of having a dewlap (i.e., an extensible skin fold in the throat region, more developed in males than in females) and widened adhesive lamellae below fingers and toes (Poe et al., 2017).

In his revision of the green anoles from Hispaniola, Williams (1965) recognized four species in this group (Anolis chlorocyanus, A. coelestinus, A. aliniger) and his new species (A. singularis). He distinguished two groups of species based on their distribution and morphological similarities: one group composed of A. chlorocyanus and A. coelestinus, and another containing $A$. aliniger and $A$. singularis.

Fifty-one years later, Köhler and Hedges (2016) made the second revision of this group, where they described eight new species, resurrected four from synonymy, and raised three taxa from subspecies to species level. They also reorganized the species groups, and thus, currently 16 species of green anoles from Hispaniola are recognized, distributed in three groups (i.e., the Anolis chlorocyanus group, the Anolis coelestinus group, and the Anolis aliniger group). As a group, these species are well distributed across Hispaniola and can be found in a variety of habitats from near sea level to more than $2000 \mathrm{~m}$ above sea level. Two of these species $A$. cyanostictus and $A$. chlorocyanus occur in sympatry along with the introduced green anole from Cuba, $A$. porcatus, in many green areas and urban parks in the city of Santo Domingo and the Distrito Nacional. Prior to Köhler and Hedges (2016) work, Anolis cyanostictus was considered as a subspecies of $A$. chlorocyanus but currently both taxa are recognized as two distinct species which can be distinguished by some external characteristics such as the dewlap coloration and the presence versus absence of characteristic pale brown blotches. Anolis cyanostictus has a yellowish-green dewlap with little or no black pigment on the posterior portion and has pale brown blotches near the shoulder and behind the eye, whereas A. chlorocyanus shows black suffusion in the posterior part of the dewlap and does not have any pale brown blotches (Mertens, 1939; Cochran, 1941; Williams, 1965; Schwartz \& Henderson, 1991; Köhler \& Hedges, 2016). These two taxa also differ in geographic distribution. A. chlorocyanus can be found throughout the eastern part of Hispaniola north and east of the Cordillera Central, whereas A. cyanostictus is restricted to the National District and nearby towns (Köhler \& Hedges, 2016) that includes its type locality, the vicinity of the Haina River in San Cristóbal province.

The introduced species $A$. porcatus can be distinguished from both species by having a pink male dewlap as well as a more robust body and a bigger size. After its introduction to Hispaniola, it used to be restricted to only a few areas of Santo Domingo (Arias, 1985; Powell et al., 1990). In recent years has been reported to expand its range to more localities (Stuart et al., 2012) but apparently, Santo Domingo is the only contact zone between these three species. Having three similar looking green anoles in sympatry raises questions about possible hybridization and competition. To address these issues, we conducted field and lab work with individuals of all three species from their area of sympatry. Here we report our results of an analysis using mtDNA sequence data combined with an evaluation of morphological characters for species identification to evaluate potential hybridization among these taxa. 


\section{OBJECTIVES}

- To evaluate whether there is evidence for hybridization among the three species of green anoles (Anolis chlorocyanus, A. cyanostictus and A. porcatus) occurring in sympatry in the metropolitan area of Santo Domingo, Dominican Republic.

\section{MATERIALS AND METHODS}

Study areas. We collected specimens from seven study sites in Santo Domingo and the Distrito Nacional: the National Botanical Garden "Dr. Rafael M. Moscoso" (NBG), three urbans parks: Parque Mirador Norte (PMN), Parque Mirador Sur (PMS) and Parque Mirador Oeste (PMO), the Plaza de la Cultura (PC), La Feria and Los Maestros.

The NBG is located in Altos de Galá, in the northwestern part of Santo Domingo de Guzmán, between the coordinates $18.490556^{\circ} \mathrm{N}$ and $69.958611^{\circ} \mathrm{W}$. It has an area of $1.28 \mathrm{~km}^{2}$ and an elevation between 70 and 80 meters above sea level. The soil is of limey origin, shallow and of low fertility, its relief is flat and with slight undulations (Mejía \& García, 1994).

The PMN is located on the northern margin of the Isabela River in the municipality of Santo Domingo Norte (Fig. 1). It is the largest protected area in the city, with an area of about $10 \mathrm{~km}^{2}$. It is characterized by having extensive forests and galleries; as well as lagoons, gullies and wetlands (Consejo Nacional de Asuntos Urbanos [CONAU], 2007).

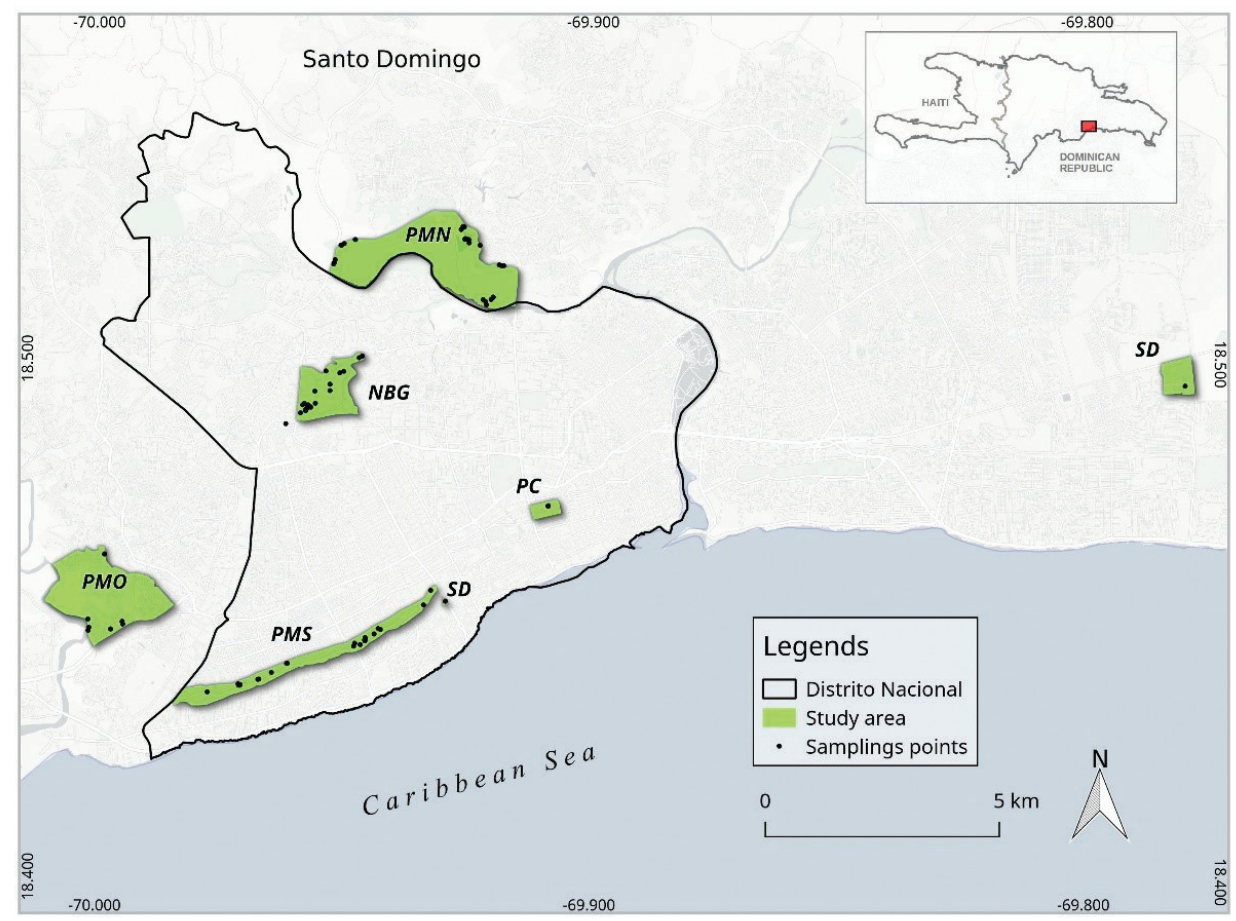

Figure 1. Sampling sites in Santo Domingo and Distrito Nacional. 
The PMS, created in 1970, was the first urban park in Santo Domingo. It is located on the avenue of the same name (Parque Mirador Sur) in the Distrito Nacional. It occupies a surface of approximately $7 \mathrm{~km}^{2}$ and presents, rock formations, caves, underground springs, bushes and scattered trees. (CONAU, 2007; Szabó, 2010).

The PC is located in the center of the Distrito Nacional. It covers an approximate area of $1 \mathrm{~km}^{2}$. Its vegetation is composed of ornamental plants, open bushes and scattered trees (Almonte-Espinosa, 2018). Currently this area is under renovation and many of the vegetation patches where the specimens were collected has been cut.

The PMO, with an area of about $7 \mathrm{~km}^{2}$, is located in the Santo Domingo Oeste municipality, near the Haina River. Together with the PMN, they are part of the so-called "Green Belt of Santo Domingo", an ecological corridor that surrounds the periphery of the city and whose function is to stop urban expansion while protecting the flora and fauna associated with each area (Ayuntamiento del Distrito Nacional [ADN], 2016).

In addition to the aforementioned areas, collections were made at two additional sites. One in the municipality of Santo Domingo Este (Los Maestros) and another in the Distrito Nacional (La Feria) near PMS. Unlike the previous ones, these points do not constitute green areas or urban parks and will be referred as Santo Domingo (SD); see Appendix A for coordinates.

Sample collection. A total of 141 green lizards were collected. The number of individuals per site was distributed as follows: NBG $(\mathrm{n}=33)$, PMN $(\mathrm{n}=38)$, PMS $(\mathrm{n}=36)$, PMO $(\mathrm{n}=20)$ $\mathrm{PC}(\mathrm{n}=8)$ and $\mathrm{SD}(\mathrm{n}=6)$. Additionally, 18 specimens were included as putatively pure individuals of each species from non-contact areas: A. cyanostictus $(\mathrm{n}=3)$, A. chlorocyanus $(11)$ and A. porcatus (4). Specimens of the two endemic species were revised and confirmed by Köhler and Hedges (2016). All the additional individuals were collected outside of Santo Domingo; see Appendix B for coordinates. Of the 159 samples (141 collected and 18 added), we only used those that could be sequenced (139), including the supposedly“"pure" ones.

Methodology. Prior to preserving the specimens collected in the field, color photographs of each individual's extended dewlap were taken, following Köhler (2014) for dewlap extension and animal position. After euthanasia, we cut tissue samples from the tip of the tail of each individual and stored them in $98 \%$ non-denatured ethanol. The specimens were preserved by injecting a solution of $5 \mathrm{~mL}$ absolute (i.e., $36 \%$ ) formalin in $1 \mathrm{~L}$ of $96 \%$ ethanol into the body cavity and thighs. We deposited part of the specimens in the collection of the Museo Nacional de Historia Natural "Prof. Eugenio de Jesus Marcano" (MNHNSD), Santo Domingo, Dominican Republic, and the remaining specimens have been deposited in the Senckenberg Forschungsinstitut Frankfurt (SMF), Frankfurt, Germany.

For DNA extraction, we followed the protocol of Ivanova et al. (2006). To eliminate potential PCR-inhibiting contaminants, the tissue samples were incubated for $14 \mathrm{hrs}$ in $200 \mu \mathrm{L}$ low PBS buffer $(20 \mu \mathrm{L}$ PBS in $180 \mu \mathrm{L}$ of water) before overnight digestion with the vertebrate lysis buffer at $56^{\circ} \mathrm{C}$. After extraction, the DNA was eluted in $50 \mu \mathrm{L}$ TE buffer. A fragment of the mitochondrial 16S rRNA gene was amplified in an Eppendorf Mastercycler ${ }^{\circledR}$ pro, using the following protocol: initial denaturation for 2 minutes at $94{ }^{\circ} \mathrm{C}$ followed by 40 cycles with denaturation for 35 seconds at $94{ }^{\circ} \mathrm{C}$, hybridization for $35 \mathrm{~s}$ at $48.5{ }^{\circ} \mathrm{C}$, and elongation for $60 \mathrm{~s}$ at $72{ }^{\circ} \mathrm{C}$; final elongation for 10 minutes at $72{ }^{\circ} \mathrm{C}$. The reaction mix for each sample contained $1 \mu \mathrm{L}$ DNA template. We used the following primers: L2510 (CGCCTGTTTATCAAAAACAT) for the forward and H3066 (CCGGTCTGAACTCAGATCACGT) for the reverse strand (Köhler et al., 2014). For each sample, $9 \mu \mathrm{l}$ of distilled $\mathrm{H} 2 \mathrm{O}+1 \mu \mathrm{l}$ of DNA was used. 
The cleaning and editing of the sequences for both primers was carried out with the MEGA 7 bioinformatics program package (Kumar et al., 2016). Once all the sequences were edited, the alignment of the multiple sequences was performed using the MUSCLE algorithm included in MEGA 7 and following the default parameters. The generated matrix was used to perform a phylogenetic analysis based on the Neighbor-Joining (NJ) method (Saitou and Nei 1987). The support of the tree branches was evaluated by boostrap (10,000 repetitions) and for the calculation of the evolutionary distances the Kimura 2-parameter method was used (Kimura, 1980). The analysis involved 140 nucleotide sequences. The species A. rodriguezii was included in the analysis as an external group (outgroup).

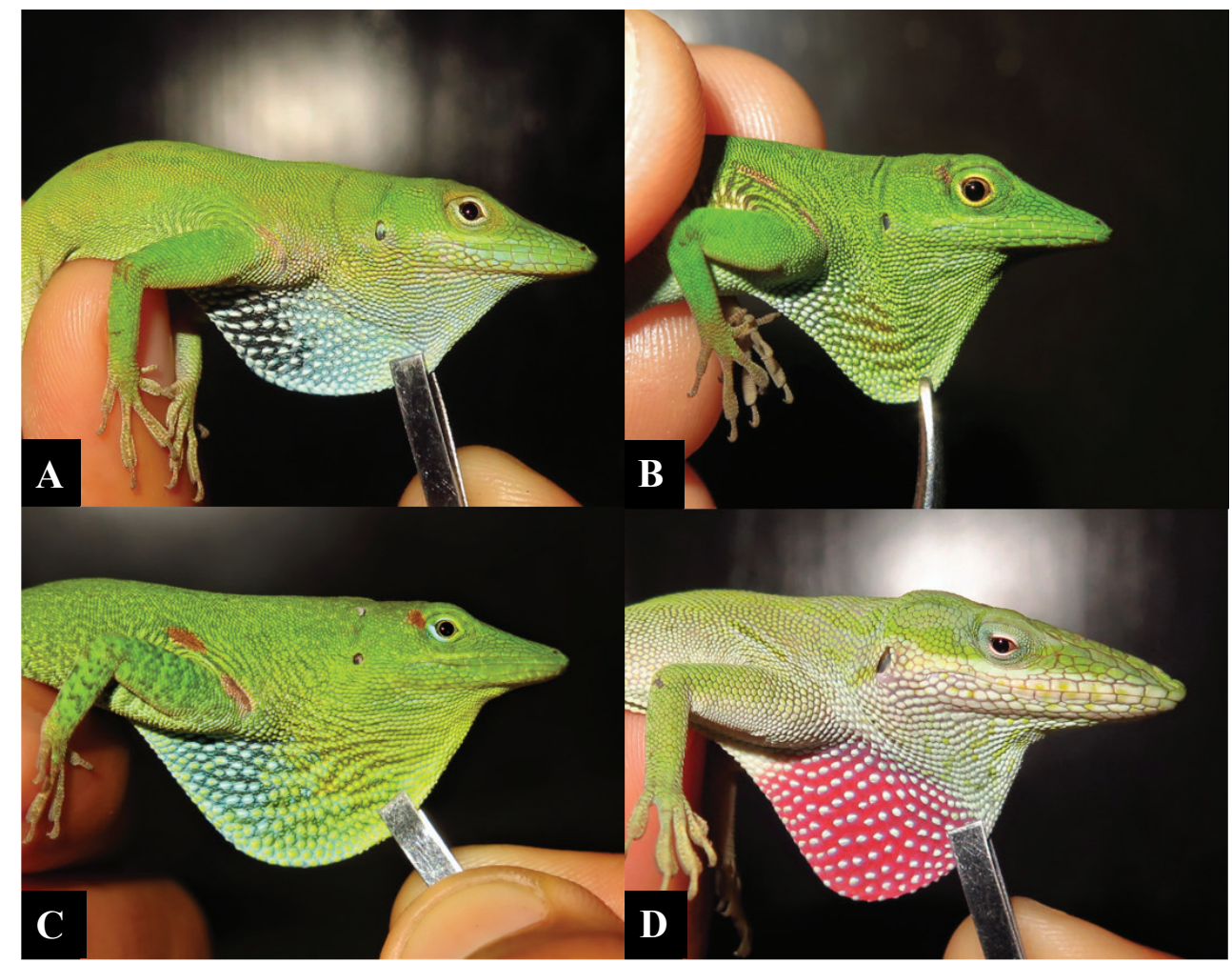

Figure 2. Representative specimens (all adult males) of the species treated in this work as well as a specimen that we considered intermediate in morphology between A. chlorocyanus and A. cyanostictus. A, A. chlorocyanus. B, A. cyanostictus. C, intermediate. $\mathrm{D}$, A. porcatus.

For specimen's examination, the photographs were revised for two characters: (1) dewlap coloration (see below) and (2) body coloration (i.e., presence versus absence of pale brown blotches above the shoulder or near eye). For dewlap coloration, we checked if there was black suffusion on the posterior portion of the dewlap and also categorized the intensity of the black suffusion (i.e., absent, weak, strong). Based on the results of this morphological evaluation, we placed each specimen in one of five categories reflecting its phenotype: $0=100 \%$ chlorocyanus phenotype; $0.25=$ intermediate, but exhibiting more of the chlorocyanus characteristics than those for cyanostictus; $0.5=$ intermediate, exhibiting equally characteristics of both cyanostictus and chlorocyanus; $0.75=$ intermediate, but exhibiting more of the cyanostictus characteristics than those for chlorocyanus; and $1=100 \%$ cyanostictus phenotype. This category number was later translated into the species ID (Table I). 
To test the null hypothesis of no association between phenotypic class (pure species 1 , intermediate, pure species 2) and mitochondrial cluster (clade 1, clade 2), we conducted a 3 x 2 Fisher's exact test.

Table I. Specimen's assignation and identification

\begin{tabular}{|llcl|}
\hline $\begin{array}{l}\text { Black suffusion } \\
\text { on dewlap }\end{array}$ & Brown spot & Assignation & Species ID \\
\hline strong & absent & 0.0 & $A$. chlorocyanus \\
\hline weak & absent & 0.0 & $A$. chlorocyanus \\
\hline strong & present & 0.5 & intermediate \\
\hline weak & present & 0.75 & intermediate \\
\hline absent & present & 1 & $A$ cyanostictus \\
\hline absent & absent & 2 & $A$. porcatus \\
\hline
\end{tabular}

\section{RESULTS}

Morphology. We collected 41 individuals (33.9 \%) with phenotypic characteristics for Anolis chlorocyanus (our category 0) and $17(14.0 \%)$ with characteristics typical for A. cyanostictus (our category 1). However, we found 36 individuals $(29.8 \%$ ) with characteristics of both species (our categories 0.5 and 0.75 , but none with our category 0.25 ). $10.8 \%$ of these 36 individuals were categorized as 0.5 , that is, they exhibited equally characteristics of both species (black suffusion on dewlap and brown blotches present); $15.1 \%$ were allocated to our category 0.75 , showing more characteristics of one species than of the other (Fig. 3). In the case of A. porcatus, the 27 individuals reviewed ( $22.3 \%$ of total samples), corresponded well to the characteristics described for this species (Fig. 2d).

Individuals of all categories and phenotypically pure species were only found at NBG (Fig. 3). At PMO, PMS and PC we found A. porcatus, and intermediates individuals along with just one of the native species. Phenotypically pure A. chlorocyanus and A.porcatus were obtained at SD. The PMN was the only locality were all the individuals, had the characteristics of the species A. chlorocyanus (Fig. 3).

The phylogenetic tree reconstructed with the $16 \mathrm{~S}$ sequences placed all the individuals in three clades: in one clade, chlorocyanus phenotypes were in the majority, the second clade consisted mainly of cyanostictus phenotypes, and in the third clade all individuals have phenotypic characteristics of the species A. porcatus. For the chlorocyanus clade, 51 of 71 individuals possess the $A$. chlorocyanus phenotype; 12 are individuals with an intermediate phenotype 


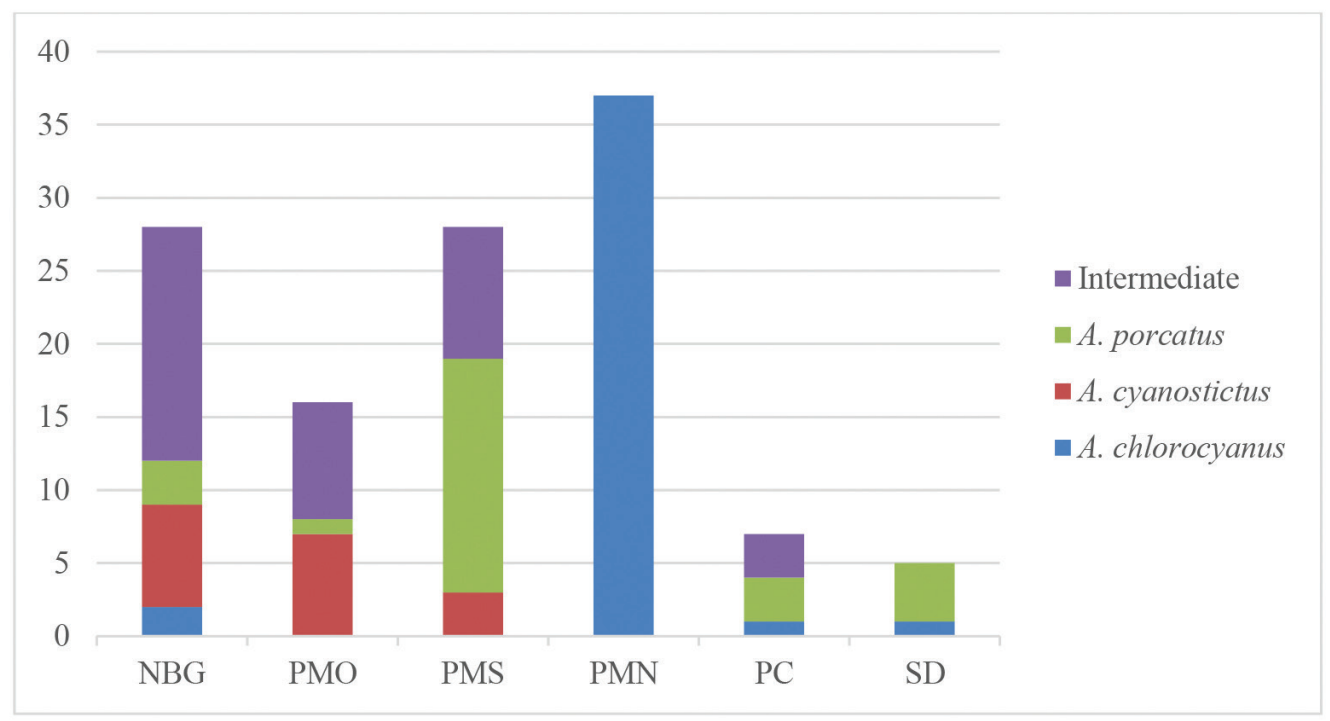

Figure 3. Distribution of specimens collected based on phenotypic characteristics.

between this species and $A$. cyanostictus, of which six were placed in the phenotypic category of 0.5 (black suffusion strong and pale brown blotches) and six specimens were categorized as 0.75 (characteristics more typical for one species than the other). In addition to these intermediates, this clade includes eight individuals with $A$. cyanostictus phenotype (Category 1 ).

The cyanostictus clade contained 37 individuals, of which 12 have the typical phenotype of A. cyanostictus (Category 1) and 24 have an intermediate phenotype between A. cyanostictus and A. chlorocyanus. Of the latter group, nine were in the phenotypic category of 0.5 , while 15 were placed in 0.75 . This clade includes only a single individual with the $A$. chlorocyanus phenotype (Category 0). We tested for a genotype/phenotype association between A. cyanostictus and A. chlorocyanus only, because of the complete association between mitochondrial clade 3 and the $A$. porcatus phenotypes. The test rejected the null hypothesis and showed a clear association of the A. chlorocyanus phenotype with clade 1 and $A$. cyanostictus with clade 2 (Table II).

Table II. Association of phenotypic class with mitochondrial clade. Given is the contingency table with the observed values followed by the expected values in brackets. The association was highly significant $\left(\mathrm{X}^{2}=46.81, \mathrm{p}<0.0001\right)$.

\begin{tabular}{lccc}
\hline & $\begin{array}{c}\text { A. chlorocyanus } \\
\text { phenotype }\end{array}$ & intermediate & $\begin{array}{c}\text { A. cyanostictus } \\
\text { phenotype }\end{array}$ \\
\hline $\begin{array}{l}\text { Mitochondrial } \\
\text { clade 1 }\end{array}$ & $51(34.19)$ & $12(23.67)$ & $8(13.15)$ \\
$\begin{array}{l}\text { Mitochondrial } \\
\text { clade 2 }\end{array}$ & $1(17.81)$ & $24(12.33)$ & $12(6.85)$
\end{tabular}



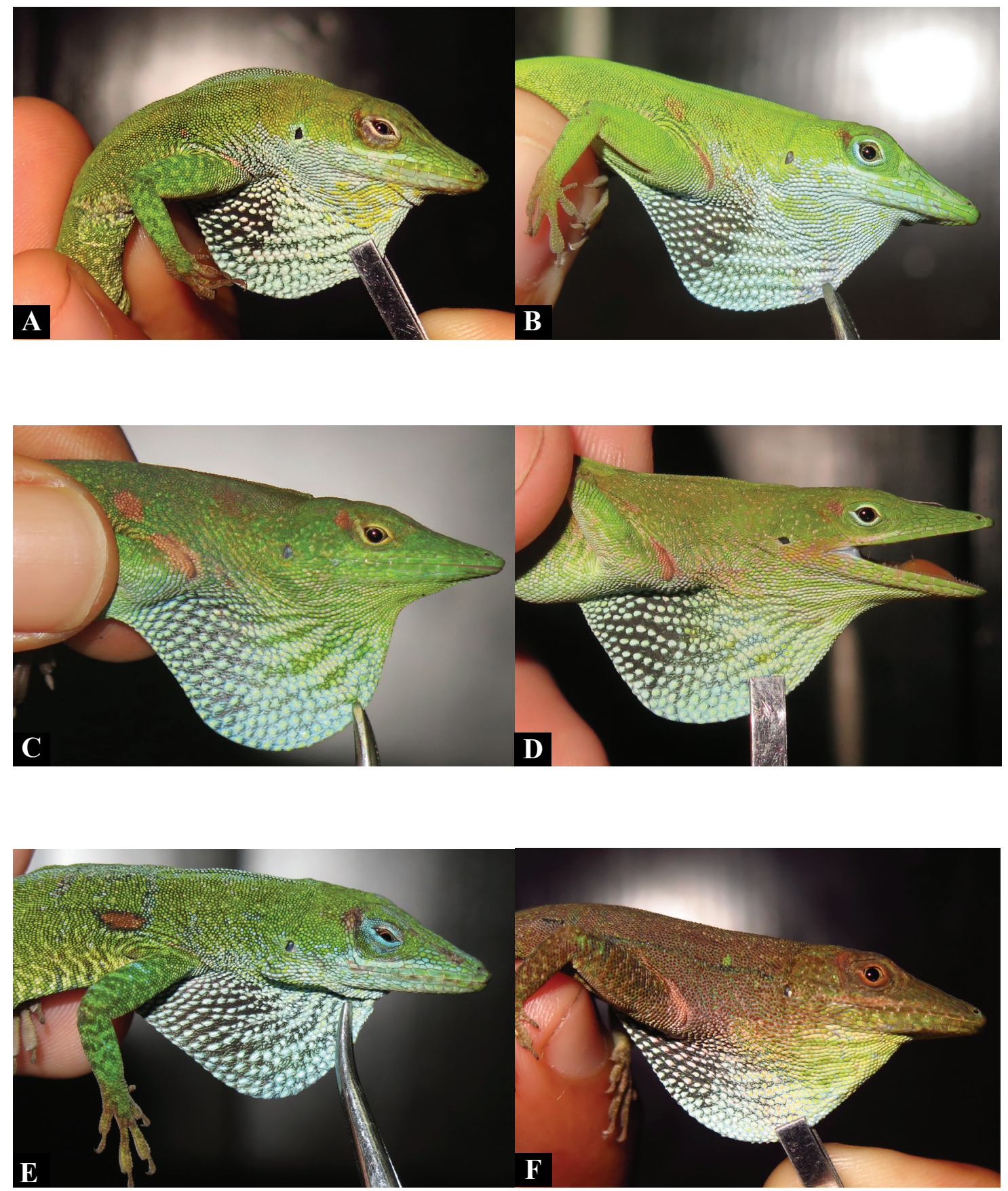

Figure 4. Intermediate individuals assigned to category 0.5. All these specimens had a strong black suffusion on dewlap and had pale brown blotches above shoulder and near eye present. A, MNHNSD 23.3767. B, MNHNSD 23.3765. C, SMF 105326. D, SMF 105319. E, MNHNSD 23.3762. F, MNHNSD 23.3766. 

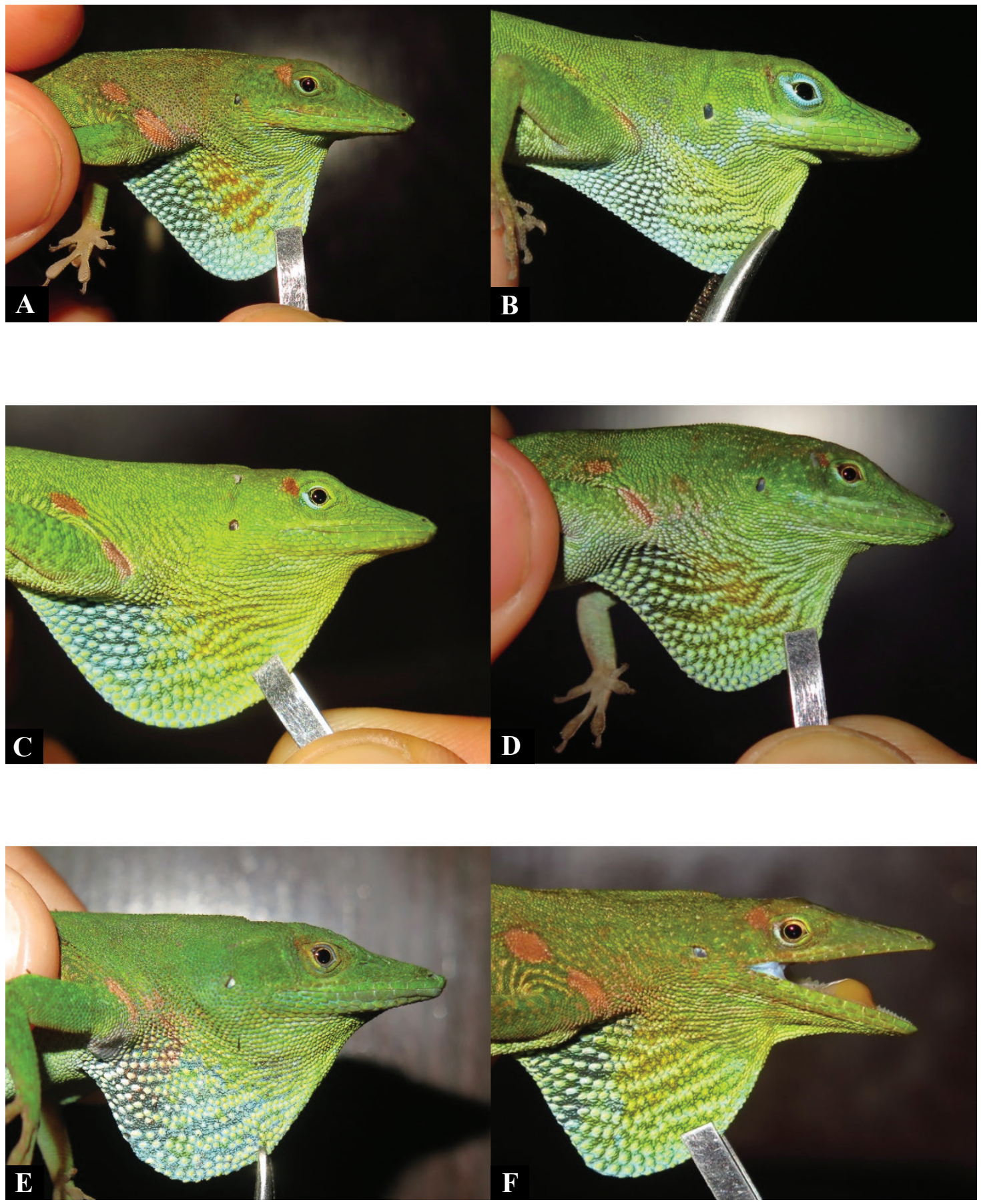

Figure 5. Intermediate individuals assigned to category 0.75 . All these specimens had the black suffusion weak and the brown spot above shoulder and near eye present. A, MNHNSD 23.3793. B, GK-5937. C, MNHNSD 23.3783. D, MNHNSD 23.3792. E, SMF 105344. F, MNHNSD 23.3746. 
FIGURE 6

(a) Anolis cyanostictus clade

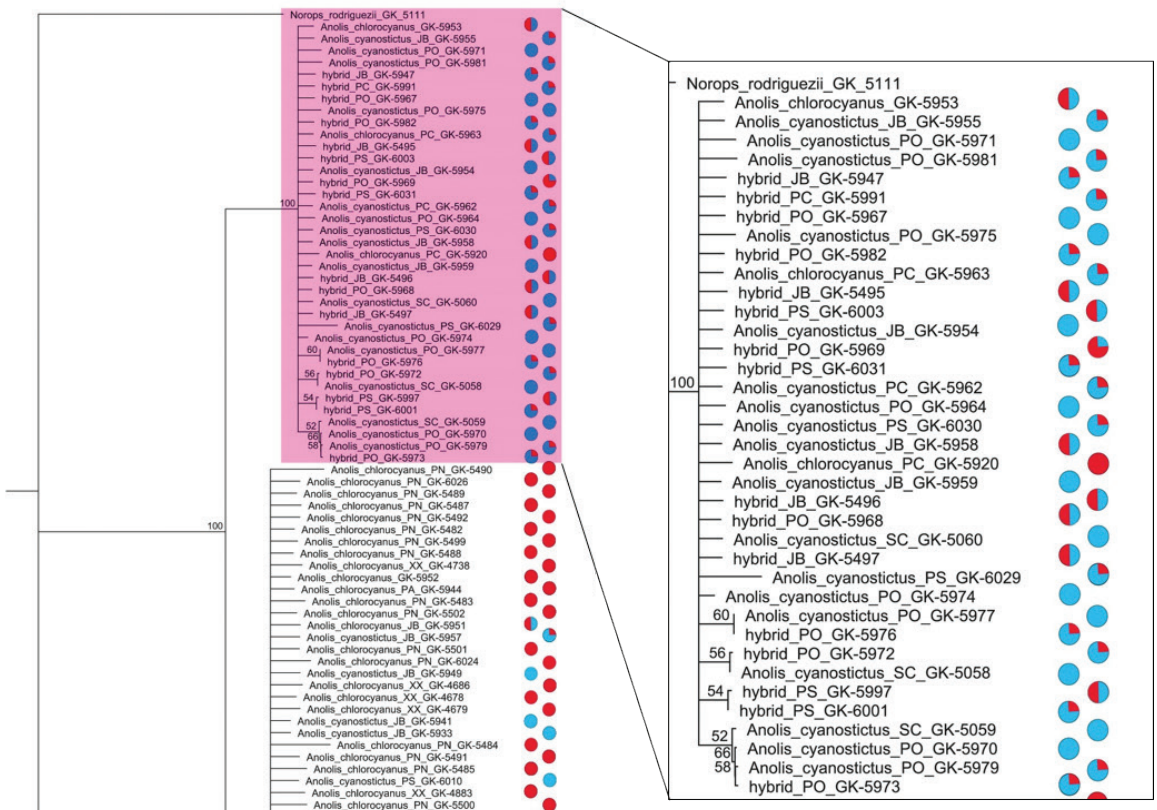


(b) Anolis chlorocyanus clade

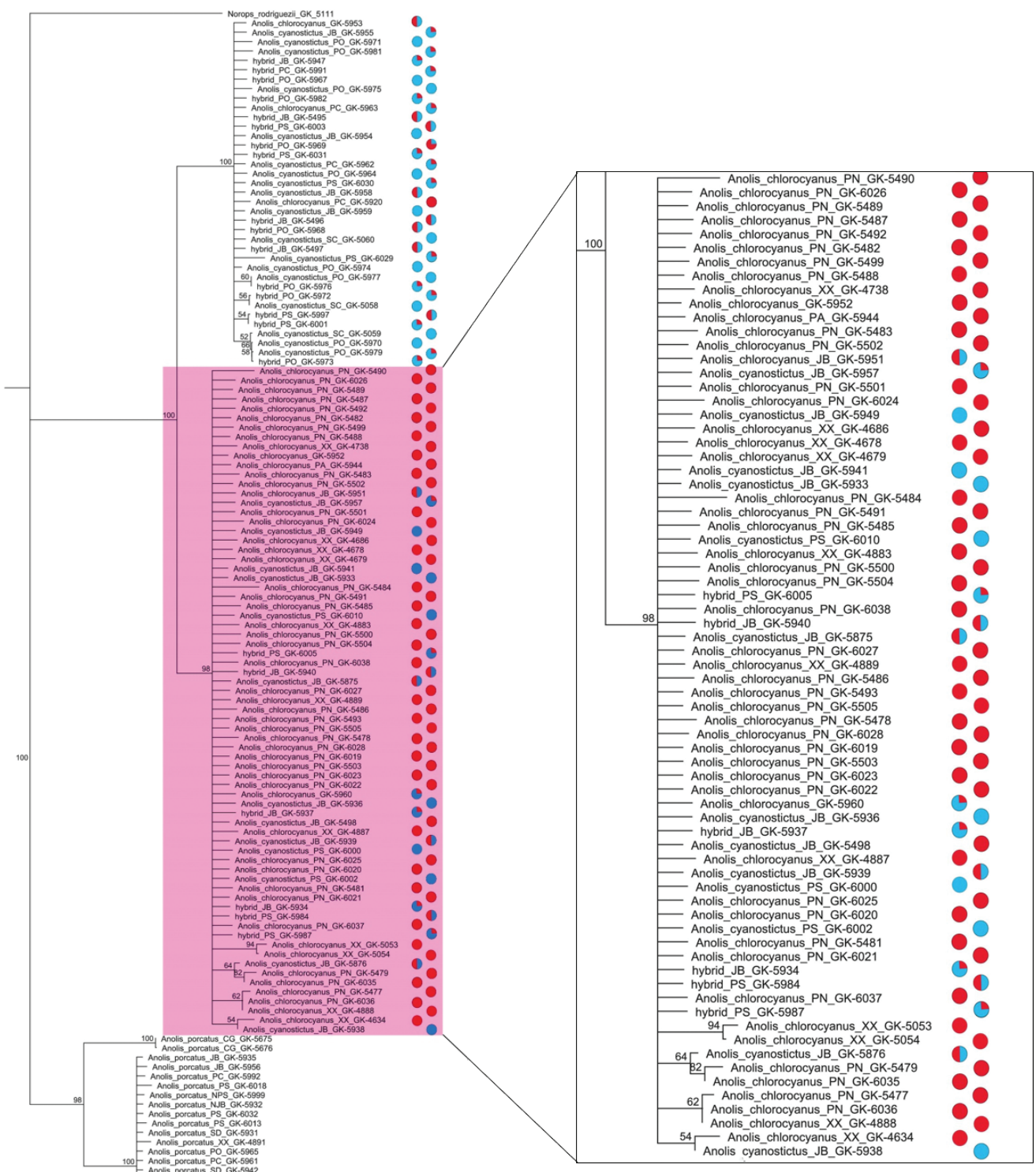




\section{(c) Anolis porcatus clade}

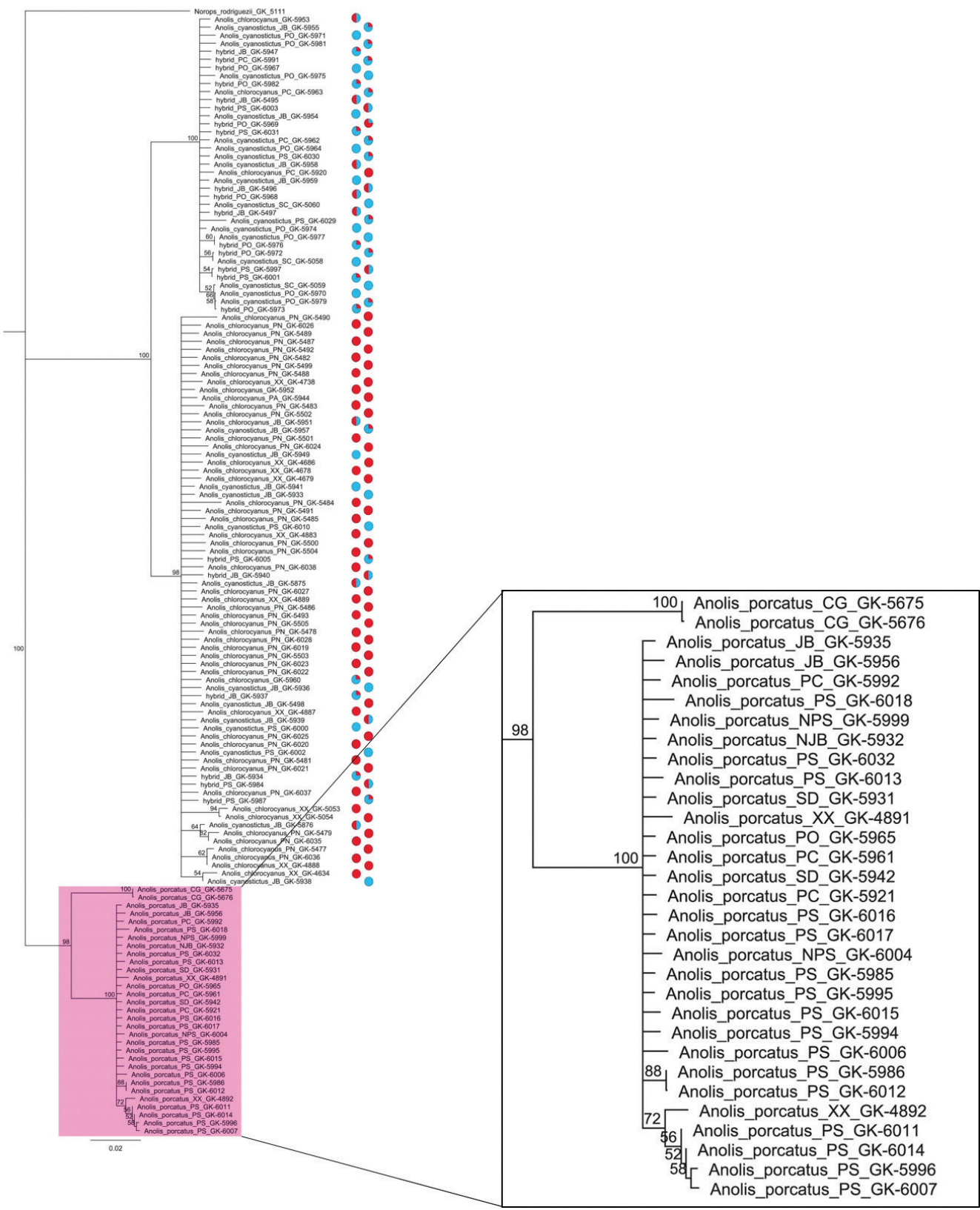

Figure 6. Phylogenetic tree obtained by analyzing Neighbors Union (Neighbor Joining, NJ) of the 16S gene sequences. The numbers at the nodes represent the bootstrap values. (a) chlorocyanus clade, (b) cyanostictus clade, (c) porcatus clade. The pie diagram shows the morphological assignment, A.chlorocyanus (red), A. cyanostictus (blue). 


\section{DISCUSSION}

According to Köhler and Hedges (2016), the evidence presented in Garcia et al. (1994) does not constitute reliable evidence for hybridization between Anolis peynadoi (formerly $A$. chlorocyanus) and A. viridius (formerly A. coelestinus). Therefore, our work constitutes the first report of hybridization between two species of green anoles from Hispaniola.

A general cyto-nuclear association between morphological (as a proxy for nuclear loci) and mitochondrial data, accompanied by incongruence in some individuals constitutes strong indication for hybridization between species (e.g., Pfenninger et al., 2002; Dépraz et al., 2009), as found between the two endemic species $A$. chlorocyanus and $A$. cyanostictus. Based on their intermediate morphology, hybrids can be placed in two groups: those showing equally characteristics of both parental species and those that are distinctly more similar in their phenotype to one of the parental species. These findings indicate the presence of backcrosses of hybrids with one of the parental species. Some hybrids were found in places where one of the species (A. cyanostictus or $A$. chlorocyanus, respectively) was apparently absent, or its existence at least not documented by us, suggesting (1) a small population of the species not found by us or instead, (2) that these intermediate individuals are the result of a historical hybridization event and that one of the two parental species had become locally extinct since, perhaps even by this introgression (Rhymer \& Simberloff, 1996).

In both clades of these species we found individuals with intermediate phenotypic characteristics and individuals whose phenotypic characteristics are typical for one species but genetically they clustered with the other. Accordingly, the lack of intermediate morphological traits is not a reliable criterion to distinguish between hybrid and non-hybrid individuals; this is similar to what was found by Cedeño-Vázquez et al. (2008), in crocodiles. In some cases, hybridization can occur due to a shortage of conspecific mating partners, especially when a rare species and a common species are found in sympatry (Wirtz, 1999). In the case of the hybrids collected in the NBG, more phenotypically pure individuals of A. cyanostictus than of A. chlorocyanus were found, suggesting that at this site $A$. cyanostictus is the much more common species and $A$. chlorocyanus is a relatively rare species. Assuming a female mate choice, it is likely that hybridization occurs mostly between females of $A$. chlorocyanus (rare species) with males of $A$. cyanostictus (common species).

The fact that only a few reports on anoles hybridization exist (e.g., Gorman \& Atkins, 1968; Glor et al., 2004; Köhler et al., 2010; Jezcova et al., 2013; Wegener et al., 2019) and even fewer reports on interspecific mating (e.g., Arias, 1985), might be interpreted as evidence of the existence of good reproductive isolating mechanisms, but could also be interpreted as a lack of combined genetic and morphologic investigations. (Schenk et al., 2008).

In the particular case of PMN, given the congruence of the morphological and the genetic results, all individuals collected were assigned to the species $A$. chlorocyanus, i.e., no specimens of the other species were caught, nor specimens with an intermediate morphology. This may be due to the fact that the Isabela River separates this park from the rest of the areas studied, possibly acting as a geographical barrier, favoring the isolation of this species and preventing the dispersal of these anoles across the river.

Interestingly, sympatry of $A$. cyanostictus and $A$. chlorocyanus along with evidence of hybridization was only documented in areas that are historically known as the range of distribution of $A$. cyanostictus, but not in the original range of $A$. chlorocyanus. We assume that the latter species is translocated with human aid, most likely by bringing decorative plants into the metropolitan area. Flower pots with substrate containing anole eggs are a likely source of anoles when brought to a new place. 
We did not find evidence of hybridization between either of the endemic species with the introduced species $A$. porcatus. However, Arias (1985) observed males of $A$. cyanostictus trying to copulate with females of $A$. porcatus, unsuccessfully due to rejection by the latter.

\section{CONCLUSIONS}

Our study revealed evidence for hybridization between Anolis chlorocyanus and A. cyanostictus in the metropolitan area of Santo Domingo, Dominican Republic. The hybrids between these two species were grouped into three categories: (1) individuals that exhibit equally characteristics of both species, (2) individuals that exhibit more characteristics of one species than of the other, and (3) individuals that phenotypically represent one of the two species but that cluster genetically with the other species. Therefore, in areas of sympatry identification at the species level based on morphology is not reliable.

\section{ACKNOWLEDGMENT}

We thank the Ministerio de Medio Ambiente y Recursos Naturales of Santo Domingo, Dominican Republic for collecting permits. We are grateful to the Museo Nacional de Historia Natural "Prof. Eugenio de Jesús Marcano" and the Forschungsinstitut und Naturmuseum Senckenberg for their support and funding of this work. We thank, Reveca Ramírez, Cristian Marte and Dalia Jones for their invaluable help during the field work. To América Sánchez for her contribution creating the map. To Linda Mogk and Sebastian Lotzkat for their help with the laboratory work and support during the visit of E. G. at the Senckenberg Museum. 


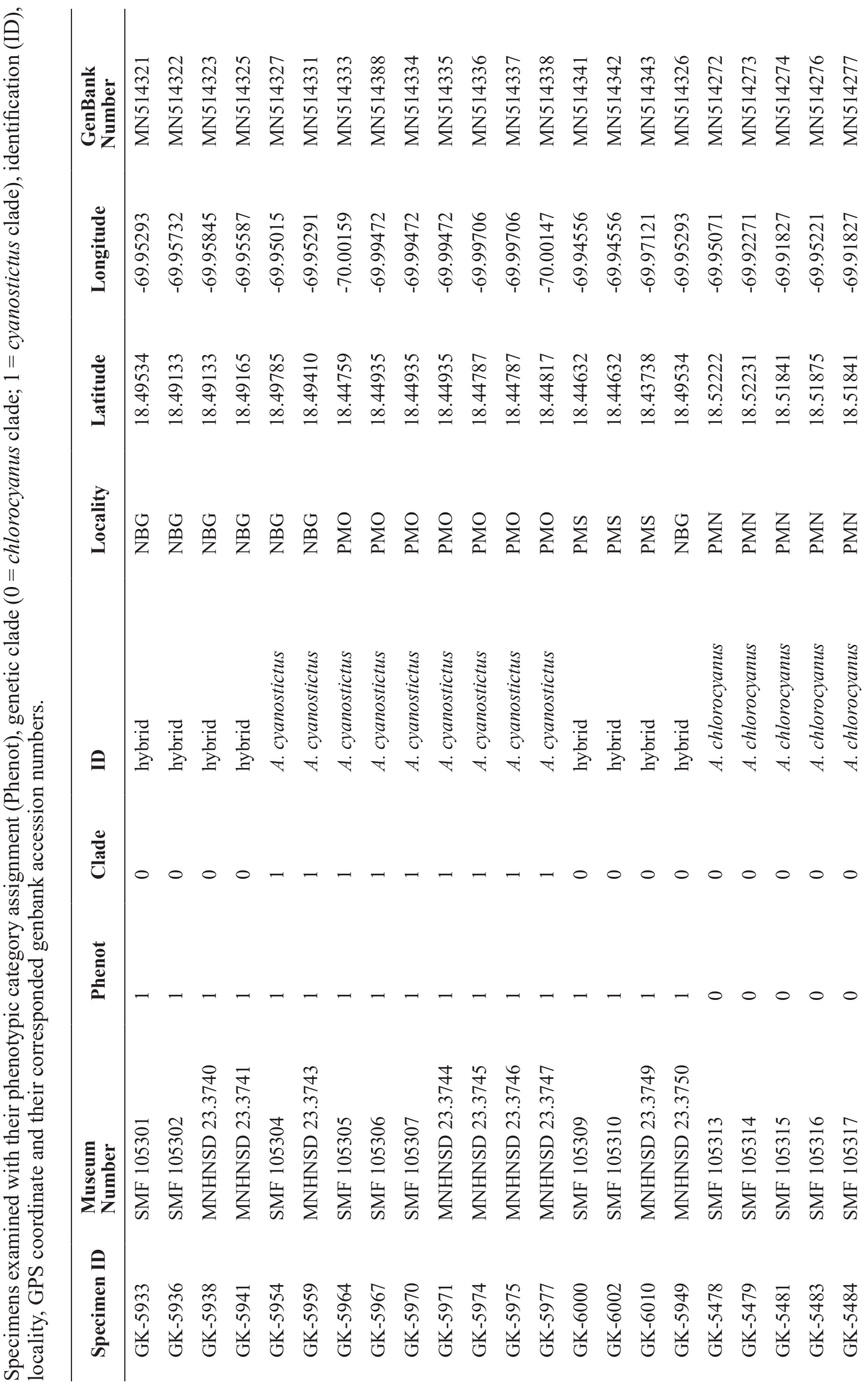




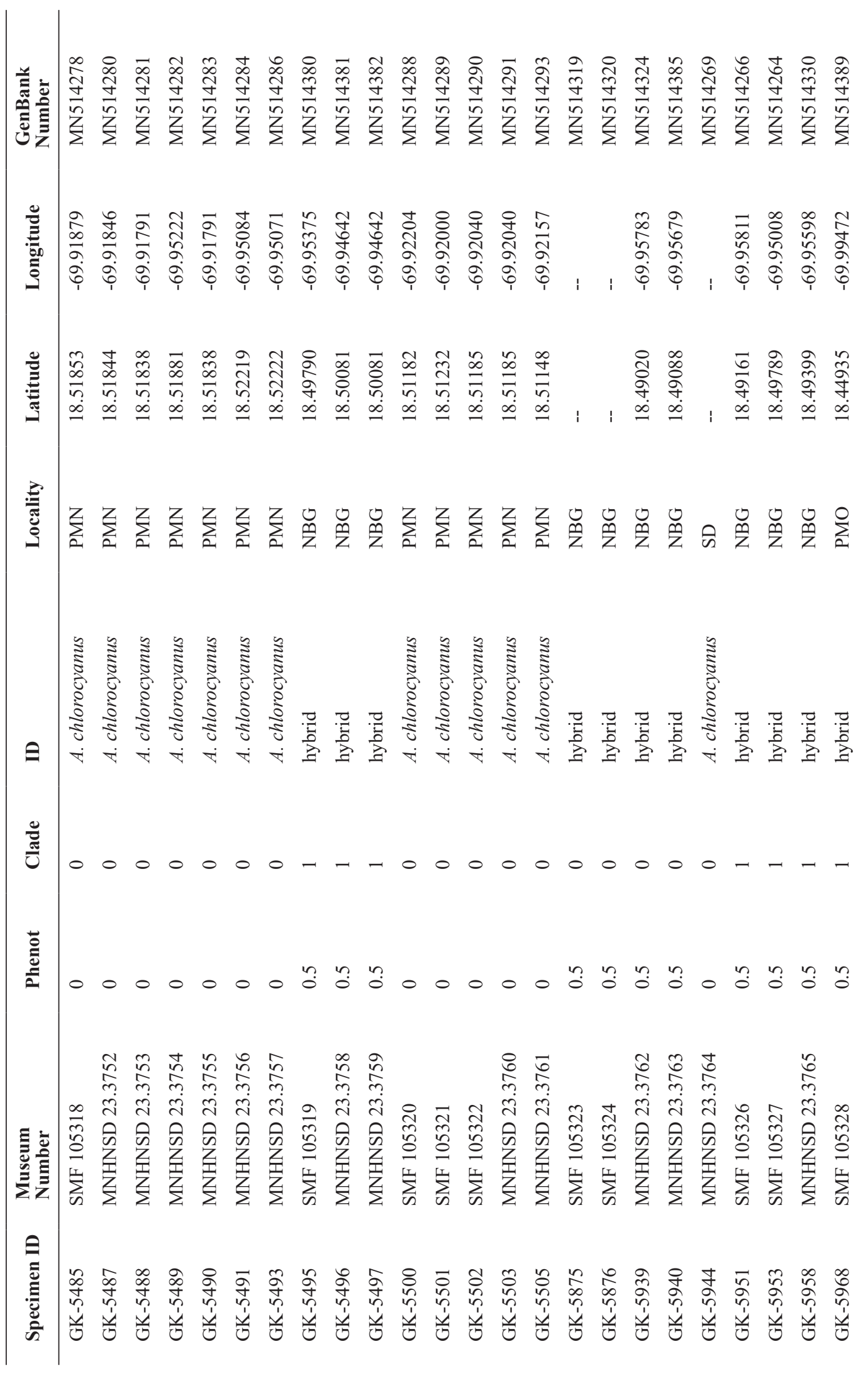




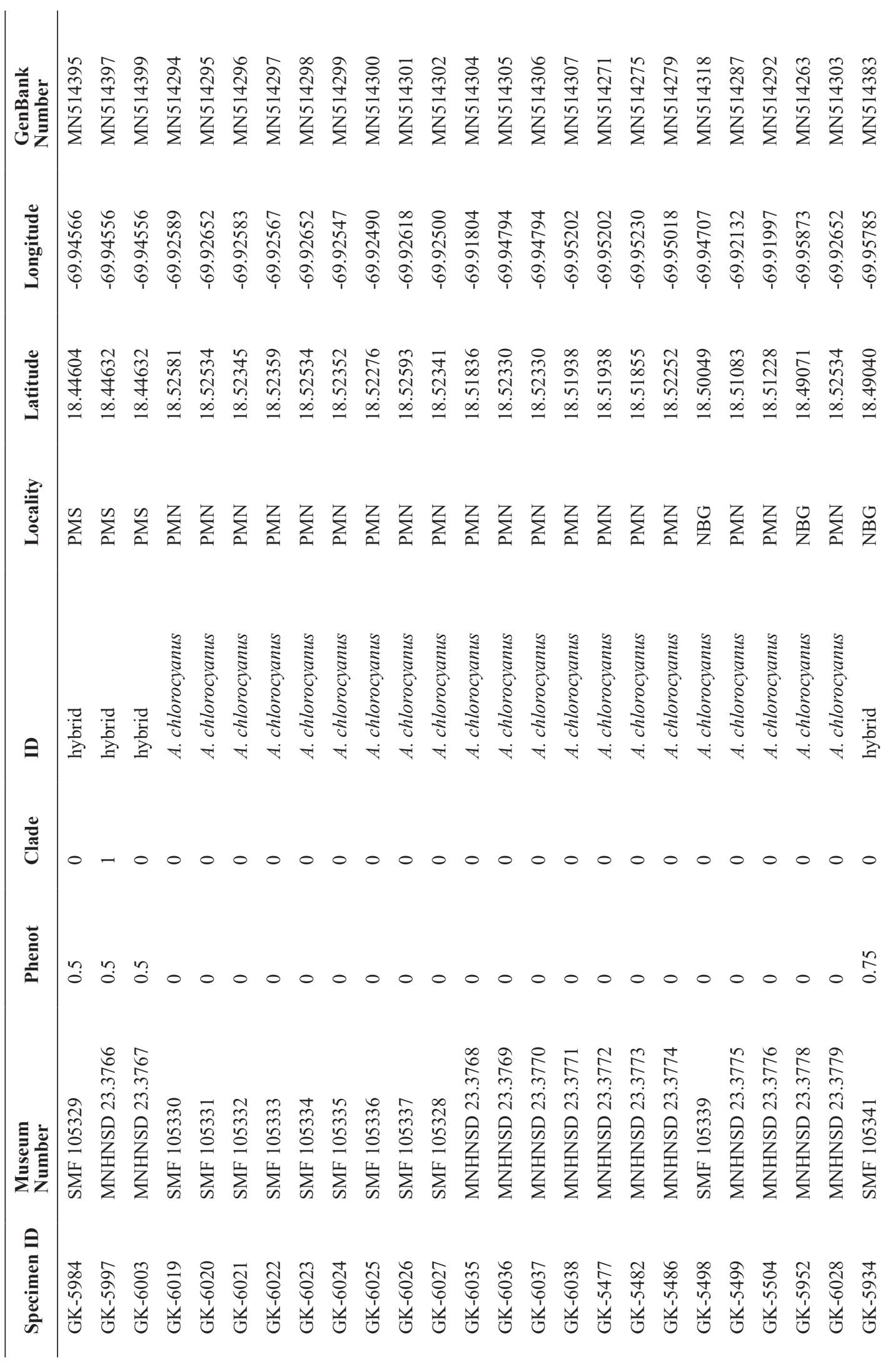




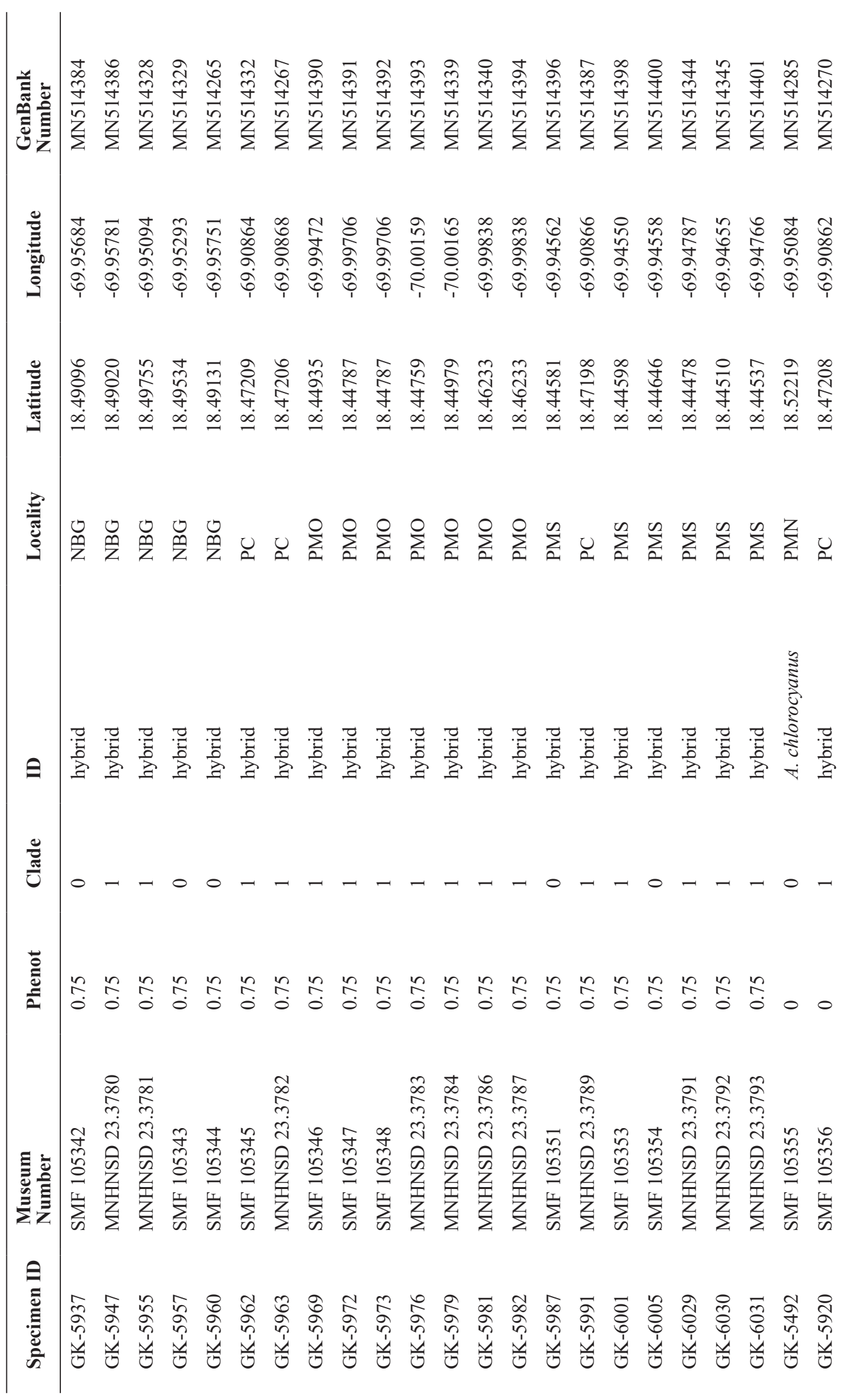




\section{APPENDIX B}

Anolis porcatus and additional specimens examined. Abbreviations of localities: NBG = National Botanical Garden "Dr. Rafael M. Moscoso, PMS = Parque Mirador Sur, PMO = Parque Mirador Oeste, $\mathrm{PC}=$ Plaza de la Cultura, $\mathrm{SD}=$ Santo Domingo, VA = Villa Altagracia, LR = La Romana, BA = Bávaro, $\mathrm{BC}=$ Boca Chica, $\mathrm{AD}=$ Autopista Duarte and $\mathrm{PP}=$ Puerto Plata .

\begin{tabular}{|c|c|c|c|c|c|c|}
\hline $\begin{array}{l}\text { Specimen } \\
\text { ID }\end{array}$ & $\begin{array}{l}\text { Museum } \\
\text { Number }\end{array}$ & Species & Locality & Latitude & Longitude & $\begin{array}{c}\text { GenBank } \\
\text { Number }\end{array}$ \\
\hline GK-5956 & MNHNSD 23.3794 & A. porcatus & NBG & 18.48978 & -69.95885 & MN514353 \\
\hline GK-5932 & MNHNSD 23.3795 & A. porcatus & NBG & 18.48768 & -69.96184 & MN514351 \\
\hline GK-6032 & MNHNSD 23.3796 & A. porcatus & PMS & 18.44141 & -69.96142 & MN514375 \\
\hline GK-6013 & MNHNSD 23.3797 & A. porcatus & PMS & 18.43835 & -69.96703 & MN514369 \\
\hline GK-5965 & MNHNSD 23.3798 & A. porcatus & PMO & 18.44885 & -69.99464 & MN514357 \\
\hline GK-5961 & MNHNSD 23.3799 & A. porcatus & $\mathrm{PC}$ & 18.47205 & -69.90863 & MN514355 \\
\hline GK-6006 & MNHNSD 23.3800 & A. porcatus & PMS & 18.43725 & -69.97080 & MN514365 \\
\hline GK-5986 & MNHNSD 23.3801 & A. porcatus & PMS & 18.44803 & -69.94247 & MN514359 \\
\hline GK-6012 & MNHNSD 23.3802 & A. porcatus & PMS & 18.43827 & -69.96722 & MN514368 \\
\hline GK-6011 & MNHNSD 23.3803 & A. porcatus & PMS & 18.43725 & -69.97080 & MN514367 \\
\hline GK-6014 & MNHNSD 23.3804 & A. porcatus & PMS & 18.43582 & -69.97744 & MN514370 \\
\hline GK-5996 & MNHNSD 23.3805 & A. porcatus & PMS & 18.44823 & -69.94293 & MN514362 \\
\hline GK-6007 & MNHNSD 23.3806 & A. porcatus & PMS & 18.43963 & -69.96449 & MN514366 \\
\hline GK-5921 & SMF 105359 & A. porcatus & $\mathrm{PC}$ & 18.47207 & -69.90862 & MN514354 \\
\hline GK-5931 & SMF 105360 & A. porcatus & $\mathrm{SD}$ & - & - & MN514376 \\
\hline GK-5935 & SMF 105361 & A. porcatus & NBG & 18.49040 & -69.95785 & MN514352 \\
\hline GK-5942 & SMF 105362 & A. porcatus & SD & 18.49575 & -69.77985 & MN514377 \\
\hline GK-5985 & SMF 105363 & A. porcatus & PMS & 18.44717 & -69.94374 & MN514358 \\
\hline GK-5992 & SMF 105364 & A. porcatus & $\mathrm{PC}$ & 18.47197 & -69.90866 & MN514356 \\
\hline GK-5994 & SMF 105365 & A. porcatus & PMS & 18.45564 & -69.93234 & MN514360 \\
\hline GK-5995 & SMF 105366 & A. porcatus & PMS & 18.45284 & -69.93379 & MN514361 \\
\hline
\end{tabular}


Appendix B. Continuation

\begin{tabular}{|c|c|c|c|c|c|c|}
\hline $\begin{array}{l}\text { Specimen } \\
\text { ID }\end{array}$ & $\begin{array}{l}\text { Museum } \\
\text { Number }\end{array}$ & Species & Locality & Latitude & Longitude & $\begin{array}{l}\text { GenBank } \\
\text { Number }\end{array}$ \\
\hline GK-5999 & SMF 105367 & A. porcatus & $\mathrm{SD}$ & 18.45357 & -69.92937 & MN514363 \\
\hline GK-6004 & SMF 105368 & A. porcatus & SD & 18.45357 & -69.92937 & MN514364 \\
\hline GK-6015 & SMF 105369 & A. porcatus & PMS & 18.43714 & -69.97083 & MN514371 \\
\hline GK-6016 & SMF 105370 & A. porcatus & PMS & 18.43714 & -69.97111 & MN514372 \\
\hline GK-6017 & SMF 105371 & A. porcatus & PMS & 18.43725 & -69.97080 & MN514373 \\
\hline GK-6018 & SMF 105372 & A. porcatus & PMS & 18.44141 & -69.96128 & MN514374 \\
\hline GK-4891 & SMF 97976 & A. porcatus & $\mathrm{BC}$ & 18.44918 & -69.60341 & MN514378 \\
\hline GK-4892 & SMF 97977 & A. porcatus & $\mathrm{BC}$ & 18.44918 & -69.60341 & MN514379 \\
\hline GK-5675 & SMF 105357 & A. porcatus & - & - & - & MN514349 \\
\hline GK-5676 & SMF 105358 & A. porcatus & - & - & - & MN514350 \\
\hline GK-5058 & SMF 99014 & A. cyanostictus & VA & 18.44004 & -69.99910 & MN514346 \\
\hline GK-5059 & SMF 99015 & A. cyanostictus & VA & 18.44004 & -69.99910 & MN514347 \\
\hline GK-5060 & SMF 99016 & A. cyanostictus & VA & 18.44004 & -69.99910 & MN514348 \\
\hline GK-4634 & SMF 97836 & A. chlorocyanus & LR & 18.43476 & -69.19080 & MN514308 \\
\hline GK-4678 & SMF 97841 & A. chlorocyanus & BA & 18.64256 & -68.34635 & MN514309 \\
\hline GK-4679 & SMF 97842 & A. chlorocyanus & BA & 18.64821 & -68.36394 & MN514310 \\
\hline GK-4686 & SMF 105311 & A. chlorocyanus & BA & 18.64735 & -68.42858 & MN514311 \\
\hline GK-4738 & SMF 105312 & A. chlorocyanus & $\mathrm{BC}$ & 18.44780 & -69.61122 & MN514312 \\
\hline GK-4883 & SMF 97858 & A. chlorocyanus & $\mathrm{AD}$ & 18.52900 & -70.00996 & MN514268 \\
\hline GK-4887 & SMF 97861 & A. chlorocyanus & $\mathrm{AD}$ & 18.52900 & -70.00996 & MN514313 \\
\hline GK-4888 & SMF 97862 & A. chlorocyanus & $\mathrm{AD}$ & 18.52900 & -70.00996 & MN514314 \\
\hline GK-4889 & SMF 97847 & A. chlorocyanus & $\mathrm{BC}$ & 18.44918 & -69.60341 & MN514315 \\
\hline GK-5053 & SMF 97840 & A. chlorocyanus & PP & 19.63135 & -70.58644 & MN514316 \\
\hline GK-5054 & SMF 97841 & A. chlorocyanus & PP & 19.63135 & -70.58644 & MN514317 \\
\hline
\end{tabular}




\section{LITERATURE CITED}

Almonte-Espinosa, H. 2018. Composición, riqueza, diversidad y abundancia de Aves en cuatro áreas verdes de Santo Domingo. Novitates Caribaea, 12: 14-24.

Arias, C. Y. 1985. Anolis chlorocyanus y Anolis porcatus (Sauria, Iguanidae) en la ciudad de Santo Domingo. Tesis para optar por el título de Licenciatura en Biología, Universidad Autónoma de Santo Domingo, República Dominicana.

Ayuntamiento del Distrito Nacional (ADN). 2016. Análisis del contexto del Distrito Nacional: Delimitación del contexto. Distrito Nacional, República Dominicana.

Cedeño-Vázquez J. R., D. Rodríguez, S. Calme, J. Perran Ross, L. D. Densmore, \& J. B. Thorbjarnarson. 2008. Hybridization between Crocodylus acutus and Crocodylus moreletii in the Yucatan Peninsula: I. Evidence from mitochondrial DNA and morphology. Journal of Experimental Zoology Part A: Ecological Genetics and Physiology, 309: 661-673.

Cochran, D. M. 1941. The herpetology of Hispaniola. United States National Museum Bulletin, 177: $1-398$.

Consejo Nacional de Asuntos Urbanos (CONAU). 2007. Geo Santo Domingo, Perspectiva del Medio Ambiente Urbano. Santo Domingo, República Dominicana.

Dépraz, A., J. Hausser, \& M. Pfenninger. 2009. A species delimitation approach in the Trochulus sericeus/hispidus complex reveals two cryptic species within a sharp contact zone. BMC Evolutionary Biology, 9 (1): 171.

García, R., A. Queral, R. Powell, J. S. Jr. Parmerlee, D. D. Smith, \& A. Lathrop. 1994. Evidence of Hybridization among green anoles (Lacertilia: Polychrotidae) from Hispaniola. Caribbean Journal of Science, 30: 279-281.

Glor, R. E., M. E. Gifford, A. Larson, J. B. Losos, L. R. Schettino, A. R. Lara, \& T. R. Jackman. 2004. Partial island submergence and speciation in an adaptive radiation: A multilocus analysis of the Cuban green anoles. Proceedings of the Royal Society of London B: Biological Sciences, 271: 2257-2265.

Gorman, G. C., \& L. Atkins. 1968. Natural hybridization between two sibling species of Anolis lizards: chromosome cytology. Science, 159: 1358-1360.

Ivanova, N. V., J. De Waard, \& P. D. N. Hebert. 2006. An inexpensive, automation friendly protocol for recovering high quality DNA. Molecular Ecology Notes, 6: 998-1002.

Jezkova, T., M. Leal \& J. A. Rodríguez-Robles. 2013. Genetic drift or natural selection? Hybridization and asymmetric mitochondrial introgression in two Caribbean lizards (Anolis pulchellus and Anolis krugi). Journal of Evolutionary Biology, 26: 1458-1471.

Kimura, M. 1980. A simple method for estimating evolutionary rates of base substitutions through comparative studies of nucleotide sequences. Journal of Molecular Evolution, 16: $111-120$.

Köhler, G. 2014. Characters of external morphology used in Anolis taxonomy: Definition of terms, advise on usage, and illustrated examples. Zootaxa, 3774 (3): 201-257. 
Köhler, G, D. M. Dehling \& J. Köhler. 2010. Cryptic species and hybridization in the Anolis polylepis complex, with the description of a new species from the Osa Peninsula, Costa Rica (Squamata: Polychrotidae). Zootaxa, 2718: 23-38.

Köhler, G., J. Vargas, \& S. Lotzkat. 2014. Two new species of the Norops pachypus complex (Squamata, Dactyloidae) from Costa Rica. Mesoamerican Herpetology, 1: 254-280.

Köhler, G. \& S. B. Hedges. 2016. A revision of the green anoles of Hispaniola with description of eight new species (Reptilia, Squamata, Dactyloidae). Novitates Caribaea, 9: 1-135.

Kumar, S., G. Stecher \& K. Tamura. 2016. MEGA7: Molecular Evolutionary Genetics Analysis version 7.0 for bigger datasets. Molecular Biology and Evolution, 33 (7): 1870-1874.

Mejía, M., \& R. García. 1994. El Jardín Botánico Nacional. Editora Corripio, 60 pp.

Mertens, R. 1939. Herpetologische Ergebnisse einer Reise nach der Insel Hispaniola, Westindien. Abhandlungen der Senckenbergischen Naturforschenden Gesellschaft, 449: 1-84.

Pfenninger, M., F. Reinhardt, \& B. Streit. 2002. Evidence for cryptic hybridization between different evolutionary lineages of the invasive clam genus Corbicula (Veneroida, Bivalvia). Journal of Evolutionary Biology, 15 (5): 818-829.

Poe, S., A. Nieto-Montes de Oca, O. Torres-Carvajal, K. de Queiroz, J. A. Velasco, B. Truett, L. N. Gray, M. J. Ryan, G. Köhler, F. Ayala-Varela, \& I. Latella. 2017. A phylogenetic, biogeographic, and taxonomic study of all extant species of Anolis (Squamata; Iguanidae). Systematic Biology, 66: 663-697.

Powell, R., D. O. Smith, J. S. Jr. Parmerlee, C. V. Taylor, \& M. L. Jolley. 1990. Range expansion by an introduced anole: Anolis porcatus in the Dominican Republic. Amphibia-Reptilia, 11: 421-425.

Rhymer, J. M., \& D. Simberloff. 1996. Extinction by hybridization and introgression. Annual Review of Ecology and Systematics, 27 (1): 83-109.

Saitou, N., \& M. Nei. 1987. The neighbor-joining method: a new method for reconstruction of phylogenetic trees. Molecular Biology Evolution, 4: 406-425.

Schwartz, A., \& R. W. Henderson. 1991. Amphibians and Reptiles of the West Indies: Descriptions, Distributions, and Natural History. Gainesville, FL, USA: University of Florida Press, 720 pp.

Schwenk, K., N. Brede, \& B. Streit. 2008. Introduction. Extent, processes and evolutionary impact of interspecific hybridization in animals. Philosophical Transactions of the Royal Society B: Biological Sciences, 363 (1505): 2805-2811.

Stuart, Y. E., M. A. Landestoy, D. L. Malher, D. Scantlebury, A. J. Geneva, P. S. VanMiddlesworth, \& R. E. Glor. 2012. Two new introduced populations of the Cuban green anole (Anolis porcatus) in the Dominican Republic. IRCF Reptiles \& Amphibians, 19: 71-75.

Szabó, M. 2010. Árboles de Santo Domingo. Ayuntamiento del Distrito Nacional, Santo Domingo, República Dominicana, 93 pp. 
Wegener, J. E., J. N. Pita-Aquino, J. Atutubo, A. Moreno \& J. J. Kolbe. 2019. Hybridization and rapid differentiation after secondary contact between the native green anole (Anolis carolinensis) and the introduced green anole (Anolis porcatus). Ecology and Evolution, 9: 4138-4148.

Williams, E. E. 1965. The species of Hispaniolan green anoles (Sauria, Iguanidae). Breviora, 227: 1-16.

Wirtz, P. 1999. Mother species-father species: unidirectional hybridization in animals with female choice. Animal Behaviour, 58: 1-12.

[Recibido: 26 de agosto, 2019. Aceptado para publicación: 24 de octubre, 2019] 